\title{
Using Men's Changing Rooms When You Haven't Got a Penis: The constitutive potential of performing transgendered masculinities
}

Catherine McNamara, Central School of Speech and Drama

\begin{abstract}
This article is a consideration of the ways that transgender performers and queer bodies in performance contribute to the ongoing formation of the category of gender. It explores the relationship between performing transgendered masculinities and the constitutive potential of the law (namely the Gender Recognition Act 2004) surrounding (trans)gender identity. The article looks at examples of performance by transgender performance artists, Jason Barker staged as part of the annual Transfabulous International Festival of Transgender Arts in 2006 and 2007 and Lazlo Pearlman in He Was a Sailor, the Sea Was Inside Him (Drill Hall, London, 2007). Trans and queer performance work is still, for the most part, left out of academic discourse within performance studies. Engaging with trans art and trans artists in relation to shifts in legislation around gender brings very specific readings into the public domain. This record of performance that takes place beyond the mainstream brings transgender and genderqueer ${ }^{l}$ performance practice to the fore.
\end{abstract}

\section{Keywords}

transgender

queer performance 
Transfabulous

Gender Recognition Act

Jason Barker

Lazlo Pearlman

Queer performance creates publics by bringing together live bodies in space, and the theatrical experience is not just about what's on stage but also about who's in the audience creating community. (Cvetkovich 2003: 9)

Trans performance work still finds itself left out of academic discourse about performance studies. This article explores the performance of transgendered masculinities and considers the significance of these performances as they go beyond offering a call for recognition of an identity category. In the quotation prefacing this article, Ann Cvetkovitch comments on the social and intra-personal nature of the performance event or 'theatrical experience' and the potential that such experiences have to constitute the people who are participating, performing and also witnessing, as 'publics'. By analysing particular instances of performing and witnessing theatre, this notion of the constitution of publics and communities through queer performance events and the ethical dimension to those practices will be explicated.

This article, as a record of performance that takes place beyond the mainstream, brings transgender performance practice into academic discourse. Its prior absence does not mean it is insignificant work. It means that the work and the artists have not been 
recognized because of the marginal nature of their identities and practices. The performance work discussed in this article can be contextualized by looking at queer performance practices, as distinct from more orthodox forms of theatre-making and performance. I discuss the performance of transgendered masculinity in relation to the constitutive potential of the law surrounding gender identity in the United Kingdom. This article is a consideration of the ways that trans performance and queer bodies in performance contribute to the evolution of the category of gender and to the constitution of the practice of queer as a lived experience.

I draw on examples of performance by transgender performance artist Jason Barker staged as part of the annual Transfabulous International Festival of Transgender Arts in 2006 and 2007 and transgender performer Lazlo Pearlman in He Was a Sailor, the Sea Was Inside Him (Drill Hall, London, 2007). The first section of this article begins with a brief discussion of the ways I utilize the terms 'trans' and 'queer'. I then offer an explication of the constraining potential of the law in relation to trans and genderqueer identities. Normalization of gender identity is enacted through legislature but the performance artists presented here use the arts to trouble the ways that the law impacts on lived experience.

The ethical dimensions of this theatre practice include the complexities of narrating the self and the ethics of the non-normative body in performance as well as issues of inclusion and representation of marginalized identities. The stakes are high when, for example, a male performer reveals his body onstage and his body carries the scars of surgery from having breasts removed or his genitalia are not what an audience might expect them to be. Using a naked non-normative gendered body in performance 
challenges and interrogates the stability of the category of gender. The performances discussed in this article challenge dominant heteronormative ideals and they also celebrate trans and queer bodies and identities. Where theatre and performance are used as strategies to upset the logic of gender normativity and to argue for legitimacy for nonnormatively gendered people, one question that arises is the extent to which that argument reaches those who deny legitimacy to a transgender person: do these performances speak only to the converted? This article explores some of the ethical complexities that surround performances by transgender men.

The broader project of my ongoing research is to construct a corpus of transgender masculinities that appear and are represented onstage and in performance spaces. In mapping artists' work, a compilation of activity can be generated that ordinarily goes unrecorded because of when and where it takes place, and because of the subjectivities at its core. Through this research I am creating a record of ephemeral practices that has not hitherto existed. The artists under discussion are almost wholly uncited and undocumented in academic writing.

\section{Trans/gender/queer}

Categorization is useful to me as a researcher, and is also a useful organizing principle in everyday life. Where individual people find it productive to self-identify as trans in some way for example, grouping and categorizing is worthwhile. Categorization is useful too when we are looking to catalogue lived experiences as part of building a readable history. To problematize the act of categorizing is, however, also worthwhile, and is something 
that many trans and queer artists engage in as part of their art-making or their everyday lives. Categorization is context specific and 'transgender' as a category has evolved through time and in relation to other categories. For example, Susan Stryker and Stephen Whittle describe transgender as a term of choice for

a wide range of phenomena that call attention to the fact that 'gender', as it is lived, embodied, experienced, performed, and encountered, is more complex and varied than can be accounted for by the currently dominant binary sex/gender ideology of Eurocentric modernity. (2006: 3)

'Transgender' describes a person who feels that the sex and gender assigned to them at birth is not a correct or complete description of what they are or feel themselves to be. The term can be used to describe a wide range of gender expressions, which are variations from the normative though the term itself is not universally accepted as appropriate by all those who may be described by it: it is a complex category. I am utilizing a category in order to make use of the fact that categories can create and communicate meaning, and are vital in the project of mapping histories while at the same time, using categories critically and testing the borders of their meanings and the multiple ways they can be inhabited, understood, applied, refuted and challenged.

The majority of published research on transgender-related issues is concentrated in the United States. The Transgender Studies Reader (Stryker and Whittle 2006) is a collection of essays by approximately 50 authors, at least 35 of whom are American or have worked primarily within American medical or academic institutions. There was a 
boom in the production of research and academic writing on trans in the 1990s, partially in response to Gender Trouble: Feminism and the Subversion of Identity (Butler [1990] 1999) and the reprinting of The Transsexual Empire: The Making of the She-male (Raymond [1980] 1994). Raymond considers transsexuality to be a behavioural desire and argues that transsexual people never become men or women, but remain the man or woman of their birth sex, so remain 'constructed' men or women, thus undermining the very existence of the experiences of the transsexual person. Trans-theorist critiques of this perspective are vehement. Carol Riddell says 'Janice Raymond's book is an example of hatred and exclusion. An academic intellectual, she has been infested by another aspect of the patriarchal she professes to attack' (1996: 186). While there is an implication here about the hegemonic nature of academia, the key point is that Raymond's rhetoric has been accused of being anti-feminist. These are not solely theoretical arguments. In denying trans as a lived experience, one denies trans people their sense of self and thus the theoretical conceits become difficult to engage with productively. There is significantly less academic writing that takes account of and comments upon, transgender histories and experiences in the United Kingdom, though interest began to grow in the mid-2000s as the result of a developing social agenda around rights and responsibilities (see e.g. Whittle et al. 2007; the Department of Health's series of publications including Whittle and Turner 2007; Gendered Intelligence and GALYIC 2007; Hines 2007). Recent and significant changes in UK law are beginning to impact on lived experiences and interestingly, are being explored through performance practice. 


\section{The performance practice: Using Men's Changing Rooms When You Haven't Got a Penis}

Jason Barker has performed solo stand-up comedy routines at various Transfabulous events such as the Genderqueer Playhouse (an evening of comedy as part of the 2007 International Festival of Transgender Arts) where he presented the piece titled Using Men's Changing Rooms When You Haven't Got a Penis. The evening of performance promised to be 'a veritable cornucopia of lounge-like, cabaret-esque, burlesq-ish genderkaleidoscopic talent' (Transfabulous International Festival of Transgender Arts 2007). The diversity of trans identities within this talent-pool or range of artists was rich and complex, and though less broad, there were a range of races, faiths and ethnicities represented too.

Transfabulous was a collective that existed between 2004 and 2009 and was based primarily in East London. The group aimed to support, promote, exhibit and encourage transgender arts and artists. It was established by Jason Barker and Serge Nicholson and the key events produced have included the International Festival of Transgender Arts in 2006, 2007 and 2008, as well as several single-evening events, all seeking to develop an audience for transgender performers, film-makers, storytellers, musicians and comedians. The producers have also organized London's marking of the International Transgender Day of Remembrance and an annual Picnic for Change (a fundraising event for Press for Change). ${ }^{2}$

Barker and Nicholson's definition of 'Transgender Community' was and still is an inclusive one. They welcomed any transgender person or those questioning their gender, their families, friends, colleagues and supporters. ${ }^{3}$ Transfabulous provided the 
opportunity for the transgender community to celebrate their artists and to participate in the creation of art. Within this inclusive ethos, there was a distinct 'queerness' to the organization and the work it hosts and promotes. The emphasis was on diversity of gender identity and sexual orientation, and the people that gravitated towards Transfabulous (performers, artists and audiences) reflected a broad range of gendered expressions, including (but not limited to) transsexual, transgender and genderqueer people.

In the performance piece Using Men's Changing Rooms When You Haven't Got a Penis, Barker enters the stage in swimming shorts and goggles, with a backpack containing a towel and other accoutrements he needs when swimming. Jason's half-naked body is key to the comic nature of this entrance. He is a little overweight, pale skinned and has two scars from bilateral chest surgery. He presents an imperfect masculine figure that is both 'normal' and non-normative in one body. His physique is in some ways very common of a man in his late 30 s and yet his scars are the scars of a transgender man, thereby marking him as unusual. As soon as he is centre stage by the microphone, he swaps his goggles for spectacles. This action, performed by a semi-naked, slightly overweight man, endears him to this audience. He creates a comical image of a goggled swimmer out of place in a theatre space to let us know what the act will be about, but as he cannot actually see without glasses, he breaks the 'joke' in order to continue: a joke, in itself.

The act, as the title suggests, is an observation on the ways that men's and women's changing rooms are two totally different cultural spaces and Barker shares his perspective as someone who has used both during his life experience. In Lacanian terms, Barker can 
be seen as having to 'subject[s] his public life to the laws of urinary segregation' (Lacan 2006: 501). Lacan uses this idea and his simple diagram of two doors with 'Ladies' and 'Gentlemen' written above them to describe the way that primacy is granted to the signifier rather than the signified: the system of urinary segregation creates the categories of men and women rather than naming distinctions that already exist. Barker offers a comic reflection on what it is like to use the men's changing rooms of a swimming pool when you do not have a penis and when therefore, fellow-bathroom users might not classify you as a man. He talks about the problem of what to put in the netting part of his swimming shorts, in place of a penis. He tells us about his 'sponge penis' and his anxieties about it floating free of his shorts as he swims. He articulates his imagined horrors of seeing his penis bobbing about in the fast lane, and of the lifeguard fishing it out of the pool. He then demonstrates how he undresses under a towel, so as not to expose his genitalia to other users of the changing room. As he takes his shorts off under the towel, he pauses momentarily, a lone figure onstage, and whispers with a mixture of shocked realization and glee to the audience of 150 people, 'I'm naked! All those dreams I've had ... where everyone's looking at me ...!' He again plays on the image of the vulnerable emasculated figure but points beyond, to the liberatory potential of nakedness. As the piece progresses, Barker describes an awkward interaction with a fellow man, also changing after swimming. The man comments, 'I know you're a tit man cos you're trying to grow your own'. At the previous Transfabulous Festival in 2006, Barker performed the piece Moobs, a comic reflection on man-boobs, ${ }^{4}$ and specifically on his own body. He has had chest surgery to remove breasts although he talks about getting older, and gradually decreasing his dose of testosterone and therefore having a re-growth 
of breast tissue and/or body fat as a man. The humour within the swimming pool scene of the 2007 act is darker and relies on what seems to have been a veiled but threatening comment about Barker's physicality. The wry humour comes when he tells us he did not know what to say: 'You know when you get home after something like that, and all these witty lines come into your mind? Well, I still have none ... and it was two years ago'. The humour is interrupted, and the thoughts that are provoked press home the fact that Jason risks challenge and personal attack when he enters a public space, particularly a space designated as a space for men because his body carries the marks of his surgery and his version of maleness does not fit with images and ideas of normalcy.

Revealing the body is a relatively common device in performances where the body has a complex relationship to gender. Trans bodies can be deployed to problematize the constraints of a fixed identity, to blur the boundaries of masculine/not masculine, man/woman, male/female, penis/penis-less, to reveal the body through impersonation, drag, queer-drag, and parody of masculinity and/or femininity. In performing transgender masculinity and performing queerness, Barker is using performance to critique heteronormativity, and uses popular forms of entertainment such as in this case, stand-up comedy, to do so. Both performers described in this article are using their body to call for a challenge to assumptions and expectations that arise from gender normativity. Performance that utilizes a non-normative body in strategic and sometimes explicit ways is then a resistant and queerly political act, and also a fine act to balance in terms of ethics. Deirdre Heddon (2004) talks specifically about autobiography's function within a contemporary culture of intolerance. This idea is useful as a context for trans-identified performers and their work where it draws on their lived experiences, in that 
contemporary as well as historical cultures generate the need for community through marginalization, and for a marginalized individual's insistence on the right-to-be as a gendered being:

Communities, as most often conceived, operate through a process of inclusion/ exclusion. In order to have a community, there must be a boundary separating those who belong from those who do not (and the former relies on the latter). Shared narratives are one process of erecting and maintaining a boundary. (Heddon 2004: 221-22)

\section{Recognizing gender through the law}

To provide some context for recent legal shifts relating to gender identity in the United Kingdom, progress with the Gender Recognition Act 2004 (GRA) has led to a rejuvenation of the debates in the legitimization of trans. Transsexuality and transgenderism are modes of being that are characterized by shifts, changes and transition. Trans people are engaged in decision-making processes about what becomes visible and what remains invisible to others, what is 'public' and what is 'private' in terms of their identity and expression of self. The GRA supports people's rights within the workplace and other public sectors. Six years on from the Act coming into force, the Equality Act 2010 developed the category of Gender Reassignment to include transsexual and transgender people such that Gender Reassignment is now a protected characteristic within anti-discrimination legislation. Prior to the $G R A$ trans people were not recognized 
in their acquired gender (however it was expressed) under the law of any part of the United Kingdom.

The GRA addresses some aspects of social life that can make negotiating gender challenging for trans people. In positioning a trans person 'for all purposes [...] as being of the acquired gender [male or female]' (see 'Explanatory notes' (8): 2), the GRA confers the same rights to marriage, parenthood, benefits and pensions, discrimination, and inheritance as non-trans people, thus, we might say, legitimizing them. In the context of a politics of trans visibility, the GRA is seen by some, however, as being too limited in its scope for recognizing and legitimating those with a complex relationship to gender in that for example, when applying for a Gender Recognition certificate (which allows a new birth certificate to be created), the criteria an applicant must be able to meet still subscribe to the mental health model of conceiving of transgender lived experience. The requirement for evidence to prove that the applicant 'has or has had gender dysphoria' (GRA 2004, Section 2(1)(a)) necessitates that a report be provided from a medical practitioner that includes a diagnosis of gender dysphoria (a category within the American Psychiatric Association's Diagnostic and Statistical Manual of Mental Disorders, 2000). Thus legal recognition is dependent on a person being characterized as mentally ill:

This is problematic in the instrumental sense that assertions of rationality serve to undermine the prospect of legal recognition. It is also objectionable in terms of the broader discourse that it fosters in which transgender people, as a 
class, are stripped of their rationality and therefore their autonomy. (Sandland 2007: 38)

Further criticism of the GRA, suggests that by making people 'male' or 'female' their potentialities to be 'trans men' or 'trans women' are disavowed. In the film The Lovers and Fighters Convention (Mike Wyeld 2009), Jason Barker comments on the opportunities the $G R A$ presents for people, saying:

this is fantastic. This is great and it's great that people have the option but it's also then very easy for that kind of transness to just slip away. You know, people can transition and then it's like the history can be erased and we were thinking well let's make something so that this history isn't erased, and so that stories are still being told so we actually have a culture, which is what we wanted - a culture of transness. (Wyeld 2009)

Barker is keen to use the arts as a vehicle through which a range of individual expressions and identities can be recognized and celebrated, which is in addition to and, perhaps for some, in opposition to the way that this legislation has the potential to recognize their gender. When he talks about 'that kind of transness' slipping away, Barker is making reference to people who transition from the sex and gender they were ascribed at birth, to an acquired sex and gender. Sometimes, people who make that transition choose to keep their gendered history private and the law now enables that privacy to be fully protected, thus the potential erasure of trans. There is an insistence on permanence in the GRA, and 
while this need not necessarily be an irreversible surgical alteration to the body, there is certainly a requirement to promise to 'continue to live in the acquired gender until death' (GRA 2004, Section 2(1)(c)). Not all trans people fit within this binary gender order that the notion of permanence or complete transition creates. Transfabulous projects include, for example, There is No Word for It (2009), which was inspired by Eve Ensler's Vagina Monologues project - so a 'Trans Mangina Monologues'. The production, directed by Lois Weaver, drew on transcripts from interviews with a number of female to male trans people and celebrates trans male sexuality. The monologues explore aspects of lived experiences including childhood and family, transitioning bodies, growing old, male privilege, sex and genitalia. The show premiered in June 2009 at The Pinter Studio, Queen Mary University of London, and at the Soho Theatre, London with a cast of five trans men, all of whom occupy a particular position in relation to transness and to queerness.

I posit that the arts - and specifically performance practice - can contribute to the creation of a culture of transness that reflects the diversity and fluidity of identities and gendered expression, thereby retaining people's histories and the histories of particular communities. The challenges as I see them are ethical challenges in that practitioners and artists will be seeking to ensure that this culture or a history of this cultural practice is strengthened and not constrained by the law, and moreover, to ensure that people's own stories and histories are expressed, recorded and archived in ways that respect the full range and nuances of individuals' lived experiences.

David Valentine comments on the ways that trans identity and personal narrative connect with institutions such as the medical or legal system saying, 'identity is not 
something that simply arises from the self and its experiences but is the product of an ongoing process of meaning-making which draws on, and is drawn into institutionalized categories of selfhood' (2007: 223). He talks specifically about the ways that the self is narrated in relation to the state in order to make sense of violence, where a person harnesses the power of narrative force for political ends to appeal to particular agencies in order that transphobic violence gets addressed. He acknowledges that the negative side to this engagement with the state is that one has to narrate oneself through those institutional frameworks, sometimes at the expense of other aspects of the self such as race, class and sexual orientation. Ethically speaking then, perhaps there is a risk of the erasure of parts of the self when foregrounding gender. I would argue, however, that theatre practice such as that discussed in this article has the potential to facilitate and articulate a broader range of facets of personhood.

\section{The performance practice: He Was a Sailor, the Sea Was Inside Him}

Vivian M. Patraka talks about 'binary terror' within feminist performance, saying this notion names a 'terror released at the prospect of undoing binaries by those who have the most to gain from their undoing' (1992: 176). By undoing the binaries of male and female, and of masculine and feminine through live performance, a lived experience of the social system that is gender is articulated. At the same time, we might say that binary terror is invoked when a viewer sees a body with male and female signifiers, such as a penis-less man, a drag-king performer, or a woman with a beard. This terror, or instability that comes about as a result of being faced with something that undoes 'order', is seen repeatedly in everyday life in relation to expressions of transgender identity because, to 
quote Patraka once more, 'terror results because, before the undoing, what's there after it seems so uncertain and chaotic. And it is the fear of unlearning the policing habit of fear' (1992: 177). The artists in this article choose to use performance as a mode through which to comment on, and challenge this policing. Lazlo Pearlman is the second example and I am referring to his work He Was a Sailor, the Sea Was Inside Him (2007). The piece was directed by Christine Harmar-Brown and performed from 16 to 27 May 2007 at The Drill Hall, London:

Becalmed in the middle of nowhere, Salty Bugger the Sailor is simply waiting for something - anything - to change. Lazlo Pearlman has lived the same moment. When the door to himself was finally revealed he had to make the choice between sailing into an unknown horizon, or battening down the hatches and waiting for the squall to pass. What happens when the door of change opens? Do you walk through it, or walk on by? Sail into the unknown like Salty Bugger, or stick to chartered waters? He Was A Sailor... explores the unknown in gender, and the tension of the moment before, during and after the storm of change. (UK Theatre Web Archive)

The play opens with Pearlman as Salty Bugger, standing upstage left on a small plinth, encased in a sack, closed around his neck with only his bald head sticking out. He is still but not frozen, looking interestedly around at the audience entering the auditorium, as though waiting. He is lit by a soft spotlight and is close to the audience in the small 50seat studio space. For this production the seating is arranged around small tables, in a 
cabaret-style formation and the effect of this character standing calmly and so close as the audience enter and choose their seats adds to the intimacy of the space.

During the ensuing 'episodes', more characters are encountered, all played by Pearlman using straightforwardly simple shifts in position, physicality and vocal delivery, costume and light. The character of Salty Bugger has a harsh voice, questioning everything that he sees around him in a rapid, relentless fashion. This questioning often uses contemporary song lyrics as its text, so for example Salty asks: 'Do you know where you're going to? Do you like the things that life is showing you? How did you get here? This is not your beautiful house!' This character challenges everything around him and does so in an almost stream-of-consciousness style. So we are told that a sailor who is adrift at sea needs to eat citrus fruit at regular intervals in order to stay healthy, and Salty Bugger asks what the difference is between tangerines, clementine oranges and mandarins. This question links to another thought about what makes one thing different to another thing, and what makes similar things similar. He is thinking out loud about the ways that category and classification are decided upon.

In He Was a Sailor, the Sea Was Inside Him nudity is not a central feature but it is something Pearlman feels has power onstage. He says:

I'm not interested in telling you I'm a trans man. For one thing, you won't believe me, and you'll read me as a bio, possibly gay guy. The question is how do you make trans visible in a body that's not visible as trans? Displaying my body locates me inside my work. I also do want to use my body to represent the explosion of binary gender. (Pearlman 2007b). 
In a sequence where the performer transitions from another character, back into the character of Salty Bugger, he pokes a pair of semaphore flags out of the opening of the sack around his neck and then bursts out of the sack, performing embarrassment as his body is naked. He inches across the stage, holding the semaphore flags over parts of his anatomy: his face, to hide his blushes, his chest to hide his nipples and his groin to hide his genitalia. This episode is played for comedy, as Pearlman variously conceals and reveals parts of his body, in a manner reminiscent of titillation. He moves upstage right, to a white Captain's outfit displayed on a tailor's dummy. He takes each item of the outfit and dresses himself, leaving the trousers until last, thereby leaving the lower half of his body naked until the last moment to sustain the subject of the revelation through to the point at which he fully becomes Salty Bugger. I suggest that the revelation brings the focus of the spectator momentarily back to Lazlo Pearlman the performer and away from the narrative of the piece being unravelled onstage and generates a process of dualreading. Pearlman talks about creating more complex metaphors through which to talk about trans as one version of change and upheaval. Turning to the body could be said to remove some of that complexity in that a disjuncture comes about between the imagination (stimulated by textual dexterity and intricate characters) and the visual image (the flesh and the genitals of the performer). However, I argue that because Pearlman's body itself is complex, it enhances and extends the layers of meaning being offered to the audience.

Disruption or disturbance occurs when people are prompted to look again and to think about what they thought they knew about gender presentation and gendered bodies. 
Where a female-born person passes as male, the surface of the body's appearance appears to be something, and the more complex deeper details of the body and psyche of the person complicate that appearance. This complexity of what gender is exerts pressure on the idea of a coherent or stable gender identity. Butler's often quoted example of the way that a performance of gender is an intervention into the performative is the act of drag. In the introduction to the 1999 edition of Gender Trouble: Feminism and the Subversion of Identity, she addresses the issues that had been raised by her critics in relation to this point, saying:

if we shift the example from drag to transsexuality, then it is no longer possible to derive a judgement about stable anatomy from the clothes that cover and articulate the body. That body may be preoperative, transitional, or postoperative; even 'seeing' the body may not answer the question: for what are the categories through which one sees? (Butler [1990] 1999: xxii, original emphasis)

Without wishing to blur the clarity that Butler offers around the fact that performativity is not about performance in its theatrical sense, I maintain that a presumed coherence or stability of gender can be undone through theatre and performance by transgender and genderqueer artists.

\section{Representation and reception in alternative spaces}


Trans performance work is still largely absent from academic discourse. Engaging with trans art, trans artists and trans viewers of trans art in relation to shifts in legislation around gender identity and gender reassignment, brings very specific readings into the public domain. The work discussed here is variously trans through the biography of the artists, the specific and the broad social contexts in which the work is produced, the mode of aesthetic presentation and so on. Jason Barker and Lazlo Pearlman offer a challenge to gender and to transgender as a construct or category. More significantly though, their work captures what Muñoz (2009) calls an ethos of hope. Both artists use performance and the liveness of the physical transgender body onstage to critique the normativity of our presentness 'for the purpose of imaging and enacting an enabling of queer futurity' (2009: 111).

The performance of lived experiences and autobiography is a popular and familiar form for trans people who choose to tell their stories and talk about non-normative identities, whether in fiction, on film or, much less often, onstage. Stephen Whittle asserts that transgender people "have built upon the tradition the community has of autobiographical writing to give a voice to their self-acknowledged subjectivity' (1996: 208). He is talking here about numerous ways that a sense of an organized community of transgender people emerged in the 1990s, and the parallel increase in the number of trans people who began to contribute to theoretical discourse on transgender lives and identities. He sees the use of autobiography as a key tool in reclaiming the voice previously discredited by the medical and academic establishments. Dean Spade also talks about the strategic deployment of self-narrative in relation to trans people's necessity to construct an 'appropriate biography' as they enter the medical system and 
begin the process of seeking treatment for gender reassignment (2006). Stories told by self-identified trans men in the everyday or onstage are politically and ethically crucial, whether they are laymen's stories challenging experts' stories by offering a critique of medical and scientific discourses or accounts of lived experience that challenge religious discourses of sin and unnatural behaviour:

Through their stories, then, the storytellers not only claim identities for themselves, but they may also attempt to rewrite what those identities mean ... The act of writing enacts the writer, bringing [her] in to existence as matter. (Heddon 2004: 221)

The analysis of the use of performance in the constitution of transgender masculinities offers insight into the performance practices and the lived experiences of identity formation as articulated by the artists I document. While these particular lived experiences are singular and specific, when brought together and considered through the framework of performance analysis, the richness and multiplicity of transgender identities can be highlighted in a different way from that of a transsexual narrative offered in an autobiographical text or in a medical case study of a patient. The scope and range of ethnographic studies such as Devor's FTM (1999) are certainly broader than this research into performance practice, and are in many senses more comprehensive in that they gather accounts of a considerable number of lived experiences from numerous individuals and seek to thematize those experiences. But analysing and documenting transgender identities in performance and the social contexts within which those 
performances take place, provides a depth and a level of detail involved in the interactions that create performance experiences, as well as merely taking account of individual perspectives on gender. This is as a result of the individuals involved (the audiences and the performers) being in the experience together. Mangan describes the performance space as a transactional space, saying

[I]t demands and depends upon an imaginative contract between the performers and the audience, a collaboration between the sender and the receiver of the dramatic message, which enables the conventions of theatrical narrative to be understood. (Mangan 2003: 20)

I propose that where trans and queer performers are at work in a performance space, the identities transgender and genderqueer are also transactional. Through the participating, performing and witnessing involved in theatre practice, a constitution of queer publics is generated.

\section{References}

American Psychiatric Association (2000), Diagnostic and Statistical Manual of Mental Disorders, 4th ed., Washington, DC: American Psychiatric Association. 
Barker, Jason (2006), Moobs, Transfabulous International Festival of Transgender Arts, Oxford House, London, 17 June.

(2007a), Using Men's Changing Rooms When You Haven't Got a Penis,

Transfabulous International Festival of Transgender Arts, Oxford House, London, 16 June. (2007b), www.transfabulous.co.uk. Accessed 21 September 2011.

Butler, Judith ([1990] 1999), Gender Trouble: Feminism and the Subversion of Identity, London: Routledge.

Cvetkovich, Ann (2003), An Archive of Feelings: Trauma, Sexuality, and Lesbian Public Cultures, Durham: Duke University Press.

Devor, Holly (1999), FTM: Female-to-Male Transsexuals in Society, Indiana: Indiana University Press.

Gendered Intelligence and GALYIC (2007), A Guide for Young Trans People in the UK, London: Department of Health, http://www.dh.gov.uk/en/Publicationsandstatistics/Publications/PublicationsPolic yAndGuidance/DH_074258. Accessed 3 January 2008. 
Heddon, D. (2004), 'Performing lesbians: Constructing the self, constructing the community', in M. Gale (ed.), Auto/biography and Identity: Women, Theatre and Performance, Manchester University Press, pp. 217-38.

Hines, Sally (2007), TransForming Gender: Transgender Practices of Identity, Intimacy and Care, Bristol: The Policy Press.

Lacan, Jaques (2006), Écrits: The First Complete Edition in English (trans. Bruce Fink), New York: Norton.

Mangan, Michael (2003), Staging Masculinities: History, Gender, Performance, Basingstoke and New York: Palgrave Macmillan.

Muñoz, José Esteban (2009), Cruising Utopia: The Then and There of Queer Futurity, New York: New York University Press.

Patraka, Vivian M. (1992), 'Binary terror and feminist performance: Reading both ways', Discourse, 14:2, pp. 163-85.

Pearlman, Lazlo (2007a), He Was a Sailor, the Sea Was Inside Him..., Drill Hall Theatre, London, 24 May. (2007b), interview, 24 August, unpublished. 
Press for Change, http://www.pfc.org.uk/. Accessed 3 September 2011.

Raymond, Janice ([1980] 1994), The Transsexual Empire, London: The Women's Press.

Riddell, Carol (1996), 'Divided sisterhood: A critical review of Janice Raymond's The Transsexual Empire', in Richard Ekins and Dave King (eds), Blending Genders: Social Aspects of Cross-Dressing and Sex-Changing, London and New York: Routledge, pp. 171-89.

Sandland, Ralph (2007), 'A Critique of the Gender Recognition Act 2004', Journal of Bioethical Inquiry, 4:1, pp. 33-42.

Spade, Dean (2006), 'Mutilating Gender', in Susan Stryker and Stephen Whittle (eds), The Transgender Studies Reader, New York: Routledge, pp. 315-34.

The Stationery Office (2004), Gender Recognition Act 2004: Elizabeth II, Chapter 7, London: The Stationery Office, http://www.legislation.gov.uk/ukpga/2004/7/contents. Accessed 05 January 2012. (2010), Equality Act 2010: Elizabeth II, Chapter 15, London: The Stationery Office. http://www.legislation.gov.uk/ukpga/2010/15/contents. Accessed 26 September 2011. 
Stryker, Susan and Whittle, Stephen (eds) (2006), The Transgender Studies Reader, New York: Routledge.

Transfabulous International Festival of Transgender Arts (2007), 'Festival programme', Transfabulous International Festival of Transgender Arts.

Transfabulous and girlboy (2009), There is No Word for It, Soho Theatre, London, 18 June.

UK Theatre Web Archive, http://www.uktw.co.uk/archive/play/he-was-a-sailor-the-seawas-inside-him/L0485916137I. Accessed 20 January 2012.

Valentine, David (2007), Imagining Transgender: An Ethnography of a Category, Durham: Duke University Press.

Whittle, Stephen (1996), ‘Gender fucking or fucking gender? Current cultural contributions to theories of gender blending', in Ekins, Richard and Dave King (eds), Blending Genders: Social Aspects of Cross-Dressing and Sex-Changing, London: Routledge.

Whittle, Stephen and Turner, Lewis (2007), Bereavement: A Guide for Transsexual, Transgender People and their Loved Ones, London: Department of Health http://www.dh.gov.uk/en/Publicationsandstatistics/Publications/PublicationsPolic yAndGuidance/DH_074259. Accessed 14 September 2008. 
Whittle, Stephen, Turner, Lewis and Al-Alami, M. (2007), 'Engendered penalties:

Transgendered peoples experience of inequality and discrimination', Communities and Local Government Publications, http://www.pfc.org.uk/files/EngenderedPenalties.pdf. Accessed 14 September 2008.

Wyeld, Mike (2009), The Lovers and Fighters Convention, UK: Transfabulous.

\section{Suggested citation}

\section{Contributor details}

Catherine McNamara is Deputy Dean of Studies at Central School of Speech and Drama (University of London) and co-founder of Community Interest Company, Gendered Intelligence (www.genderedintelligence.co.uk). Catherine teaches on various undergraduate and postgraduate courses at Central as well as supervising at doctoral level. Catherine's applied theatre practice and research often engages queer-identified young people. She was, for example, Project Coordinator for Trans Youth Arts project 'Sci:dentity - What's the Science of Sex \& Gender?' - a twelve-month Wellcome Trustfunded project exploring gendered and sexed identities through the arts (www.scidentity.com).

Contact:

Central School of Speech and Drama, Embassy Theatre, Eton Avenue, London NW3 
3HY, UK.

E-mail: catherine.mcnamara@cssd.ac.uk

Notes

1 'Genderqueer' is a term that describes someone who identifies as a gender other than 'man' or 'woman', or someone who identifies as neither, both, or some combination thereof. In relation to the male/female binary, people identifying as genderqueer generally identify as 'both/and' or 'neither/nor', rather than 'either/or' man or woman. Some genderqueer people may identify as one specific gender and some see their own gender as a third gender in addition to the traditional two but there is ambivalence about the notion that there are only two genders in the world.

${ }^{2}$ Press for Change is a voluntary organization formed in 1992, which campaigns to achieve equal civil rights and liberties for all trans people in the United Kingdom, through legislation and social change. Their website (www.pfc.org.uk) hosts news on legislative developments and judicial case law, support and research on the ways the law impacts upon trans people's daily existence.

${ }^{3}$ See www.transfabulous.co.uk for information on Transfabulous events and publicity. ${ }^{4}$ Moobs (or 'man boobs') is a contemporary expression referring to men who have or appear to have breast tissue, sometimes but not always associated with the medical condition gynecomastia. 